\title{
Teaching Video NeuroImages: From 9 to 8-and-a-Half Syndrome After tPA
}

\section{The Rebirth of Fellini}

Dennis F. Cole, Jr., MD, Robert Wiggins, MD, Joseph Carrera, MD, and Bradford Worrall, MD

Neurology ${ }^{\circledR}$ 2021;96:e1699-e1700. doi:10.1212/WNL.0000000000011160

Figure 1 Focal Acute Pontine Stroke
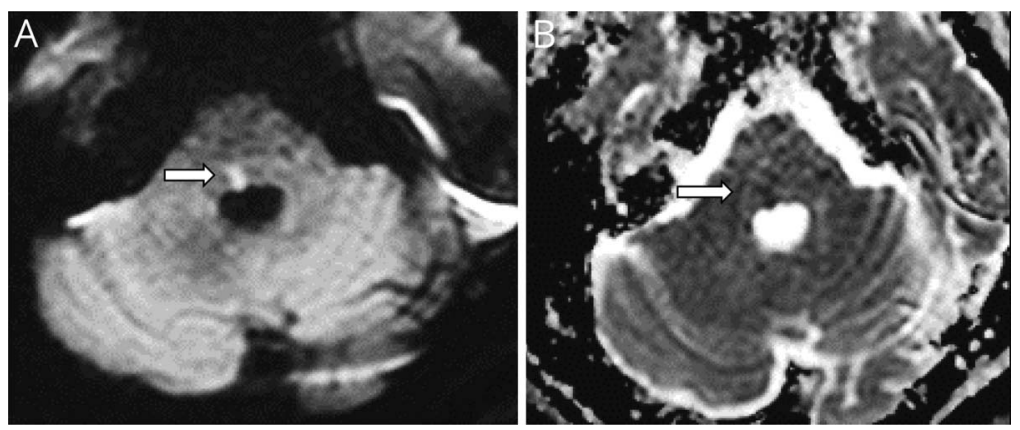

MRI with diffusion-weighted imaging (A) and apparent diffusion coefficient (B) sequences showing acute infarct (arrows) in the right dorsal pontine tegmentum in the area of the facial colliculus, medial longitudinal fasciculus, and abducens nucleus, just posterior to the medial lemniscus and corticospinal tracts, which are implicated in 9 syndrome.

A 73-year-old woman presented with acute impaired eye movements with preserved left eye abduction, right peripheral facial weakness (video 1), and left hemiparesis/hemihypesthesia. These deficits localized to the right pontine tegmentum involving the medial longitudinal fasciculus, facial nerve, abducens nucleus, medial lemniscus, and corticospinal tracts, as shown in figure 1. After tissue plasminogen activator, her left hemiparesis and hemihypesthesia resolved. Rosini et al. ${ }^{1}$ first described these deficits as 9 syndrome $(7$ th nerve +1.5 syndrome +0.5 hemiparesis/hypesthesia =9). Classically, 1-and-a-half syndrome consists of intranuclear ophthalmoplegia and conjugate horizontal gaze palsy; preserved abduction will be present in the contralateral eye. Our patient's right eye adduction was paretic and not plegic. Our patient was left with an "8-and-a-half syndrome" (figure 2). Infarct, hemorrhage, vasculitis, and demyelination are etiologies of 8 -and-a-half syndromes reported in the literature.

\section{Study Funding}

No targeted funding reported.

\section{Disclosure}

The authors report no disclosures relevant to the manuscript. Go to Neurology.org/N for full disclosures.

\section{Correspondence}

Dr. Cole

Dcole1116@gmail.com

\section{MORE ONLINE}

\section{$\checkmark$ Video}

$\rightarrow$ Teaching slides:

links.lww.com/WNL/ B268 
Figure 2 Gaze Palsy
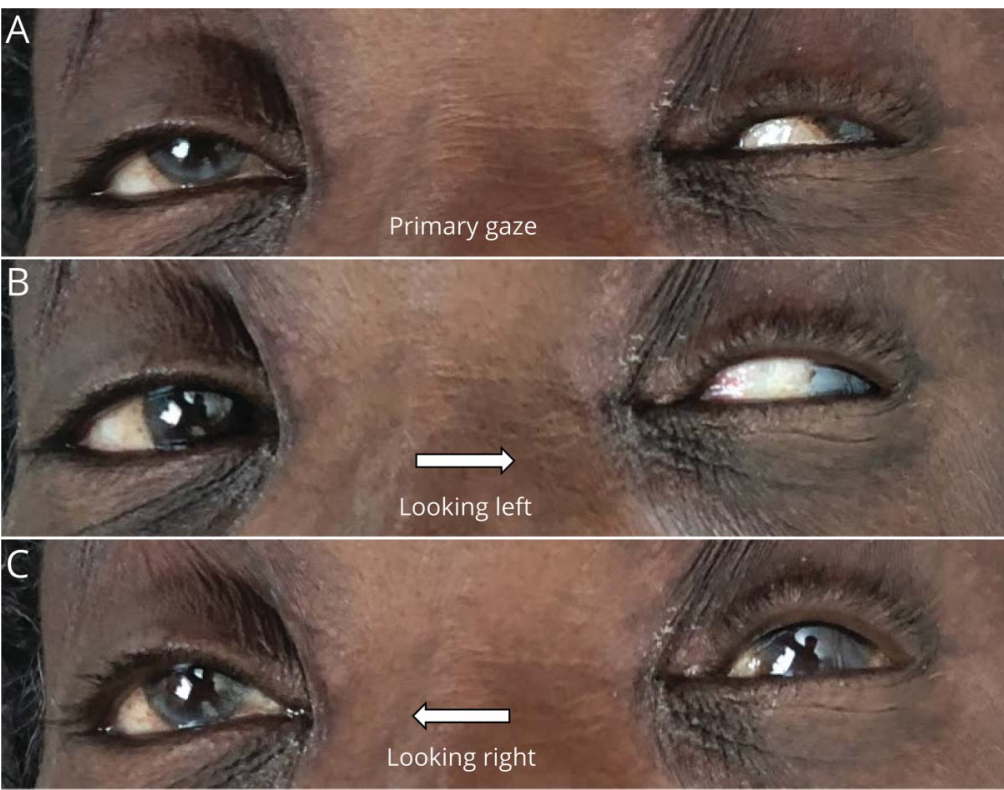

Demonstration of left eye exotropia at rest $(\mathrm{A})$, along with impaired right eye adduction (B), loss of right eye abduction and loss of left eye adduction (C) consistent with a 1-and-ahalf phenomenon.

\section{Appendix Authors}

\begin{tabular}{lll}
\hline Name & Location & Contribution \\
\hline $\begin{array}{l}\text { Dennis } \\
\text { Cole, MD }\end{array}$ & $\begin{array}{l}\text { University of } \\
\text { Virginia, } \\
\text { Charlottesville }\end{array}$ & $\begin{array}{l}\text { Acquisition of data, preparation of } \\
\text { figures, literature review, manuscript } \\
\text { drafting }\end{array}$ \\
\hline $\begin{array}{l}\text { Robert } \\
\text { Wiggins, } \\
\text { MD }\end{array}$ & University of & $\begin{array}{l}\text { Acquisition of data, manuscript } \\
\text { drafting }\end{array}$ \\
\hline $\begin{array}{l}\text { Joseph } \\
\text { Carrera, } \\
\text { MD }\end{array}$ & Unarlottesville & \\
\hline
\end{tabular}

\section{Appendix (continued)}

\begin{tabular}{|c|c|c|}
\hline Name & Location & Contribution \\
\hline $\begin{array}{l}\text { Bradford } \\
\text { Worrall, } \\
\text { MD }\end{array}$ & $\begin{array}{l}\text { University of } \\
\text { Virginia, } \\
\text { Charlottesville }\end{array}$ & $\begin{array}{l}\text { Interpreted data, revised manuscript } \\
\text { for intellectual content }\end{array}$ \\
\hline
\end{tabular}

\section{References}

1. Rosini F, Pretegiani E, Guideri F, Cerase A, Rufa A. Eight and a half syndrome with hemiparesis and hemihypesthesia: the nine syndrome? J Stroke Cerebrovasc Dis 2013;22:e637-e638.

2. Xia N, Chen Y, Li J, et al. Eight-and-a-half syndrome caused by a pontine haemorrhage: a case report and review of the literature. Int J Neurosci 2018;128, 746-750. 


\section{Neurology}

\section{Teaching Video NeuroImages: From 9 to 8-and-a-Half Syndrome After tPA: The Rebirth of Fellini}

Dennis F. Cole, Jr, Robert Wiggins, Joseph Carrera, et al.

Neurology 2021;96;e1699-e1700 Published Online before print November 9, 2020

DOI 10.1212/WNL.0000000000011160

\section{This information is current as of November 9,2020}

\section{Updated Information \&} Services

References

Subspecialty Collections

Permissions \& Licensing

Reprints including high resolution figures, can be found at: http://n.neurology.org/content/96/12/e1699.full

This article cites 2 articles, 0 of which you can access for free at: http://n.neurology.org/content/96/12/e1699.full\#ref-list-1

This article, along with others on similar topics, appears in the following collection(s):

Ocular motility

http://n.neurology.org/cgi/collection/ocular_motility

Information about reproducing this article in parts (figures,tables) or in its entirety can be found online at:

http://www.neurology.org/about/about_the_journal\#permissions

Information about ordering reprints can be found online:

http://n.neurology.org/subscribers/advertise

Neurology ${ }^{\circledR}$ is the official journal of the American Academy of Neurology. Published continuously since 1951, it is now a weekly with 48 issues per year. Copyright () 2020 American Academy of Neurology. All rights reserved. Print ISSN: 0028-3878. Online ISSN: 1526-632X.

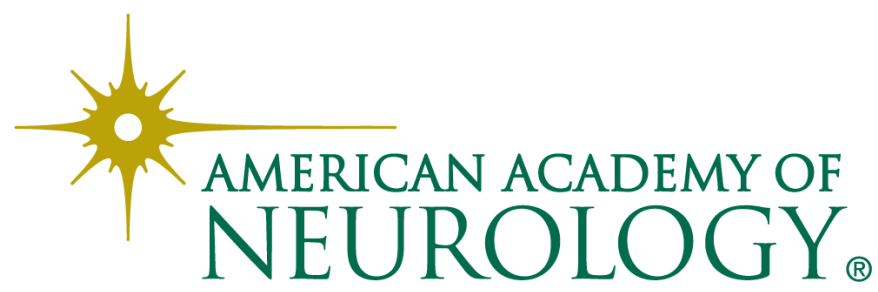

